University of Michigan Law School

University of Michigan Law School Scholarship Repository

1915

\title{
A Comparison of Some Methods of Conciliation and Arbitration of Industrial Disputes
}

James H. Brewster

University of Michigan Law School

Available at: https://repository.law.umich.edu/articles/1270

Follow this and additional works at: https://repository.law.umich.edu/articles

Part of the Comparative and Foreign Law Commons, Dispute Resolution and Arbitration Commons, and the Labor and Employment Law Commons

\section{Recommended Citation}

Brewster, James H. "A Comparison of Some Methods of Conciliation and Arbitration of Industrial Disputes." Mich. L. Rev. 13 (1915): 185-204.

This Article is brought to you for free and open access by the Faculty Scholarship at University of Michigan Law School Scholarship Repository. It has been accepted for inclusion in Articles by an authorized administrator of University of Michigan Law School Scholarship Repository. For more information, please contact mlaw.repository@umich.edu. 


\section{A COMIPARISON OF SOME ME'IHODS OF CONCTLIA'TION AND ARBITRATION OF INDUSTRIAL DISPUTES.}

T $N$ these times when we see combinations of employers co-operating under trade agreements with combinations of employees to conduct immense industries, we are apt to forget the remarkable development of ideas concerning industrial economy that has occurred within a life-time. It was only eighty years ago that the merchants of Boston met to discountenance and check what were then regarded as unlawful combinations of workmen formed: to protest against the long work day, low wages, and oppressive rules of their masters. The sum of $\$ 20,000$ was raised at this meeting of merchants and ship owners to fight the movement for a ten hour day. Such men as Wendell Philirips, Horace ManN, and Robert RANTour espoused the journeymen's cause. The right of workmen to combine for exactly these purposes, then considered by many as unlawful, has long since been recognized.

Now we see in the industrial field managers of millions of money meeting periodically the representatives of thousands of workmen in their respective industries, and forming, after conference and debate, agreements for the continuance of the industry. A comparatively new term- "Collective Bargaining"-aptly defines what then takes place.

Under the present conditions, collective bargaining seems indispensable to the peacefulness of industrial life. The vastness of our modern business enterprises and the complexity of the questions involved in conducting them make necessary the dealing of organization with organization. If negotiations are honestly and fairly conducted, and if agreements made are adhered to, industrial peace results. Employers who still decline to accept this method of maintaining industrial peace may well contemplate the words of Hon. Seth Low in his annual address of I9I2 as President of The Civic Federation. He said:

"It appears to me utterly impossible for stockholders united in a corporation to sustain themselves in the position of claiming for themselves every privilege of combination, and at the same time, to insist upon dealing with their employees only as individuals and to deny to them the right of collective bargaining. When a corporation declines to recognize a labor union, is it not doing precisely this? I understand perfectly that the employer would rather be entirely free to do as he pleases. The precise point I am trying to 
make clear is, that he cannot expect to be free to do as he pleases under the conditions of modern industry. $* * *$ The employer can decline, as he often does, to recognize a union, and in that way he can provoke strikes, which in their turn result in violence. When he does this simply because he is unwilling to recognize a labor union, he perpetuates, if he does not create, a state of war in industry; and he must share the responsibility for this result when he acts so illogically."

Because of the great and ever increasing size of our industrial organizations, and because, further, many of these organizations are engaged in business affected with a public use, the public is quite directly interested in interruptions by strike or lockout of the regular order of business, and cannot properly stand aside, as it once did, and let the parties "fight it out."

It is unfortunately true that the public often fails to recognize its interest in such disputes until the combatants draw on it for the funds with which to carry on the war; and it is further unfortunately true that even then it often lacks the patience necessary to get at the fundamental causes of the trouble,-nevertheless it is also true that society is coming more and more to realize that industrial war in the form of strikes and lockouts is an evil which should be lessened and, if possible, prevented. When industrial disputes have at length reached such a stage that they disturb the general public, as well as the immediate parties to them, we hear a great deal about rights, but very little about duties. The rights of employers, the rights of the employees, the rights of those who would be employees or employers, but are not allowed to be such, the rights of society which is composed of all these and others-these rights are insisted upon, while members of the different social groups, regarding the contest from their own point of view, overlook their mutual dependence and their reciprocal obligations.

Employers and employed seem to forget that the general public alone makes employment worth while, and the general public, having neglected its duty to provide some other means than strike or lockout for settling most industrial disputes, blames the disputants and realizes only when the war is on that it should have done something to prevent it. In ignorance of the facts, the public passes judgment upon its fellow men and condemns the one party or the other according to the prejudices of the hour.

Each dispute and each strike must be judged by its own facts; but, under usual conditions, how can the public know the facts?

Economic history shows that some strikes have been the means 
of bringing about great good; though evils, they have often displaced greater evils. Economists of repute generally concur in the opinion that while strikes may have been unwisely inaugurated in many cases, nevertheless the right to strike is, under our present industrial system, a necessary safeguard of workingmen's interests. Fair-minded employers have admitted this. Statistics prepared by government officials indicate that strikes have often proved beneficial in the long run.

Nevertheless, this hostile method of composing labor controversies ought to be used only as a last resort. But if it is to be used only as a last resort, some other earlier resort must be provided. Society is under an obligation to each and all of its constituents to provide some other way than this trial by battle for the settlement of industrial disputes. Society's annoyance does not furnish the only reason for the provision of something approaching the judicial method in these cases; another and a better reason is that it is its duty to see that justice is done after an investigation of the facts and after a study of the economic and social principles involved in such disputes.

Of course it is as vain to hope for the total disappearance of strikes or lockouts as it is to hope for the total disappearance of less public frays. People still quarrel with violence over matters which might be determined in the courts, but the fighting method of settling private disputes is generally effectively prevented by society, which furnishes courts for their adjustment, while the hostile method of settling these larger disputes is permitted because, when the parties have got beyond the conferring stage, or have never reached it, no other way is provided for their settlement.

We should not expect an exact likeness between our law courts and commissions or boards established for the settlement of industrial disputes. Our courts are the result of long evolution; legal rules are fairly well established on fixed lines; the questions to be decided generally relate to past transactions, rather than to future acts and relations. In the settlement of industrial disputes, on the other hand, there is a continuing future relation involved, and the important matters are those that are going to happen. These matters are not as capable of decision or final judgment as are the issues in an ordinary law-suit. A contract between the parties themselves is desirable in industrial disputes, rather than some other person's decision. Hence mediation and conciliation leading to a just agreement seem better than anything like a formal trial. But there often comes a time when the interests of all demand that there should be something approximating the judicial investigation and 
determination of these controversies. Various methods have been suggested to bring about these ends.

As this is a practical question, it seems worth while to examine what actually has been done, and what experience teaches on the subject.

Twenty-nine of our states have laws providing for some sort of arbitration for settling labor disputes. Aside from one or two points of general resemblance, great diversity exists among them. Judging, however, from some reports of their working, one may say that some laws which seem inadequate have produced fair results, apparently because of the men who operated them. Little can be said of other:, because they have seldom been tried.' There are three statutes which have been tested and which may be taken as typical of three different orders of laws on this subject. These are (I) the law of the United States; which may be called the Erdman-Newlands Act; (2) the Canadian Industrial DisPUTES Investigation ACT; and (3) the so-called Compulsory ARBITRATION LAW of New Zealand.

One of the results of the great railway strike of I894 and the discussions following it was the passage of the so-called ERDMAN ACT of 1898 . An earlier law of Congress was at the same time repealed.

The ERDMAN ACT applied to railroad companies and their employees engaged in train operation.

The act makes provision for mediation and conciliation, as well as for arbitration; and while arbitration was intended to be its most important function, in its practical operation mediation and conciliation have proved more advantageous and have been resorted to more frequently than arbitration.

This act remained in force fifteen years-that is, until it was replaced in July, I9I3, by the NEWLANDS ACT. For more than onehalf its life, however, it was hardly used. Nevertheless, from the latter part of 1906 until July, I9I3, it was made effective in more than sixty disputes, some of which threatened disastrous consequences. Under this law, when it had become apparent that the dispute could not be settled by the immediate parties themselves, application for mediation might be made by either side, requesting the mediators (who were originally the Chairman of the Interstate

1 The law of Wisconsin ( $\mathrm{g} g \mathrm{I}$ ) providing for an Industrial Commission is more than an arbitration law. Its general purpose is to center in one body many of the relations of employer and employee. The proper administration of such a law should render industrial disputes less frequent than they have been. See "Labor and Administration," by Professor John R. Commons, Macmillan, 1913. 
Commerce Commission and the Commissioner of Labor) to use their best efforts to induce an amicable settlement, and, these efforts failing, to try to bring about arbitration under the terms of the act.

It is important to note, as tending to show the value of even this imperfect law, that in forty-eight cases, for which definite statistics are accessible, applications have been made by both parties in sixteen instances, by employees in thirteen instances, and by railroad companies in nineteen. This ought to encourage the hope that somewhat similar means may be resorted to in other industries for the same purpose.

Moreover, when practice under this law disclosed defects, both the men and the companies showed their good will towards the purpose of the law by suggesting improvements; and many of these suggestions took legal form in the NEwI,ANDS ACr of July, I9I3, which is the ERDMAN ACT remodeled and somewhat enlarged.

For example, the duties of mediator had devolved, under the former act, on the Chairman of the Interstate Commerce Commission and the Commissioner of Labor, both having other duties to perform, but these duties had been seen to be so important, that by the NiwLANDS ACT two new offices are created, namely: that of Commissioner of Mediation and Conciliation, and that of Assistant Commissioner, and on these Commissioners will devolve the chief work connected with intervention, though two other officials, together with the Commissioner, compose the "Board of Mediation and Conciliation."

Another change made by the NEwLANDS ACr is in the provision that the mediators may, without application, and upon their own initiative, proffer their services when an interruption of traffic is imminent and fraught with serious detriment to the public interest; there was regularly no intervention by the mediators under the ERDMAN Acr unless one or both parties applied for it.

An important provision of the later act is that concerning the number of arbitrators, when arbitration becomes necessary.

The old act provided for three arbitrators: one chosen by each of the respective parties, and the third by these two; or; if they failed to agree, then by the mediators. This is the prevailing method of forming such boards. But it is clear that the burden placed upon the third arbitrator selected by this process is often too great for one man; moreover, as he must endeavor to bring the others together-for they represent opposing interests-there is apt to result a decision brought about by the splitting of differences; this often is no real settlement, but a temporary adjustment in the nature of a compromise. 
The proper composition of a board of arbitration has been the subject of much discussion; and there is room for difference of opinion concerning it. Shall the board consist of three members, or more than three? Shall there be some representatives of each party on it, or shall all its members be disinterested? Shall there be a permanent board or one for the special occasion? These and similar questions are practically of much importance. Experience has partially answered some of them.

But the success of boards of conciliation and boards of arbitration, under any law, has often been due rather to the personnel of the boards than to the manner of their selection.

It is worth noting that some of the most efficient members of such bodies have been men engaged in work generally deemed impractical, as, for example, college professors, clergymen, editors and lawyers.

A greater number than three arbitrators seems desirable: the NEWLANDS ACr provides for either three or six, a majority of whom may make an award.

There are reasons for believing that a board composed partly of members continuously employed in the work of conciliation and arbitration, and partly of members selected for the special occasion, would produce more satisfactory results than one wholly made up of permanent members on the one hand, or of those chosen for the special occasion on the other.

The ERDMtan ACT was not a compulsory arbitration law, nor is its successor. Neither employer nor employee is compelled to ask for mediation or arbitration, nor are they required to refrain from a lockout or a strike.

If arbitration is resorted to, it is because the parties so agree in writing; and in this writing they agree to many other things, among them that each will faithfully execute the award. The award is filed in the United States District Court and goes into effect as a jurdgment. The difficulty of enforcing a judgment of this kind is obvious.

Senator NEWLANDS was asked in the Senate, just before the adoption of the present law, by what means the award would be carried into effect if the parties chose to ignore it, and he replied:

"I am not prepared to state what effect would be given to the award of the arbitrators if the parties chose to ignore it. *** I would prefer not to enter upon that discussion. It -abounds in difficulties, and it will be largely a matter of prediction in which I prefer not to indulge." 
Dr. NEILL, former Commissioner of Labor, says, speaking of the ERDMAN ACT, that "in no case has there been a repudiation by either side of the award of an arbitration board."'

The force relied on in these cases to carry out the award is the force of public opinion, and the moral obligation that arises from the fact that the parties have agreed to be bound by the decision.

Public opinion has been effective in some cases where railway managers and workers have had disputes, as well as in other cases. In November, 1912, the special board of seven arbitrators made an. award in the long standing dispute between some thirty thousand employees and fifty-two railroad companies and, though it was satisfactory to the representatives of neither party, a strike of far greater dimensions than the anthracite coal strike of 1902 was prevented mainly by the force of public opinion. This award, by the way, having been made in November, it became necessary for Chairman VAN HISF, to reconvene the board during February following to decide what the award really meant. Notwithstanding this experience, the Eastern railroads and their firemen, in February, 19r3, prevented a great strike by arbitrating under the ERDMAN AC'r: the managers of the railroads acceded to arbitration under what they regarded as a defective and inadequate law in deference to public opinion and to avoid a strike, but they suggested to the public this question for consideration: whether "in thus securing temporary convenience and accommodation, they are not sacrificing their permanent welfare?"3 This is a question the public might well consider whenever there is talk of settling industrial disputes in any but a just way, or of settling them upon principles of mere expediency and temporarily, rather than upon principles of enduring equity.

Even under the somewhat inadequate law of Massachusetts, public opinion worked at least some relief during the Boston street railway strike of r912 when Mayor FITZGERALD requested the state Board of Conciliation and Arbitration to follow the law which authorized the board to investigate the dispute "and ascentain which party thereto is mainly responsible or blameworthy for the existence or continuance of the same" and to "publish a report finding such cause and assigning such responsibility or blame." It was found in this case that there was practically but one question, namely: whether the men might organize themselves by their own methods into unions without thereby endangering their employment. After the board

2 Bulletin of the Bureau of Labor, No. 98, p. 3 .

a The Survey, vol. 29, p. 743. 
took hold of the matter the strike was settled and the demands of the men were conceded.

Whether or not public opinion can be relied upon to compel the parties in industrial disputes to abide by an award, or to terminate the dispute in the absence of an award, it is at least certain that it can work effectively for anything like a just conclusion only when it is an informed and intelligent public opinion.

Under the Canadian law the first object is conciliation, though when arbitration is brought about-as it may be when conciliation fails-public opinion is there, also, the sole compelling force.

There is reason to believe that this law makes possible a more accurately informed public opinion than do most of our laws, for the simple reason that investigation precedes, rather than follows, strikes and lockouts. To judge it by its fruits, as shown by statistics and reports, its short life since March, I907, has been useful. It is designed to apply primarily to public utilities, including mines; industries in which the public has the greatest interest in continuous service.

The official report of the Canadian Department of Labor states that during the first five years of the Act, 124 applications for boards of conciliation and investigation were received, and that IIo boards were established, the 14 remaining cases being settled before the boards were appointed. Out of the IIo cases referred for investigation, 93 resulted in direct agreements after the investigation, or in such improved relations between the parties as to end the disputes. During the five years, there have been 14 instances out of IIO in which strikes have occurred after the reference to the boards, but in most of these 14 cases, there was finally an adoption in substance of the boards' recommendations. Of course, this does not necessarily mean that in 124 cases there would have been strikes but for the law, though it must show that many were prevented.

The Canadian law is based upon the sound propositions that the public has a right to know about the causes of industrial disputes, especially where public utilities are concerned; that these causes should be so known before strikes or lockouts occur, rather than after their occurrence; and, further, that if the parties to a difference can be brought together and have a frank discussion of the matters in question between them, especially in the presence of just men whom they respect, the probabilities are that an agreement will be reached.

Investigation, with a view to amicable settlement of the dispute, is the duty of the board. In effect, this investigation is compulsory, 
and while it is pending there is no suspension of work: Publicity follows investigation, and then, as a last resort, the dissatisfied party may exercise the always reserved right to strike or to lockout. Neither party is deprived of any right, though the exercise of the right to inconvenience the public is postponed. If after an investigation, often disclosing facts which in reality neither party knew; and if after friendly conferences during which passions have cooled; and if after a board's full report to an interested public-if, then, one of the parties considers it best to resort to war, in the shape of strike or lockout, he may do so-but experience has shown that, as a rule, his battle is lost before it is begun.

Without now going into a detailed examination of the machinery of this law, it may. be confidently asserted that its general principles can be adopted in properly drawn statutes in the United States so as to avoid any infringement of the well recognized rights of both employers and employees, and indeed so as to afford them both a means of justly determining disputes by reason rather than by force:

Proper modifications must be made in the law to suit our local conditions, and perhaps some improvements can be made which would apply even to Canada; as, for example, provision for a larger board than one of three members; and, perhaps, that there should be a permanent chairman rather than one appointed for each occasion. A reasonable objection urged by labor unions against this law is that during the period while a strike is prohibited, as the law stands, the employer may prepare himself for meeting an unfavorable result of the investigation by engaging strike-breakers. This matter can be provided for in any properly drawn law, so that an employer will be obliged to live up to the spirit as well as the letter of the law, which is meant to preserve the status quo until the investigation shall have been finished.

Where attempts have been made to introduce such a law in the United States, some unreasonable objections have been made by both employers and employees. These objections seem to arise chiefly from a misunderstanding of the purpose and effect of the law. It does not make it a crime to strike, nor does it deprive workers of this powerful, and perhaps sometimes useful, means of obtaining justice, as some union men have thought; nor does it, on the other hand, unnecessarily or unfairly disclose to an employer's rival the secrets of his business, as some employers have contended; nor, seemingly, does it tend to make more frequent the demands of employees on employers.

It is rather important to note that the Canadian law is not really an arbitration law; both parties may, under the law, agree to regard 
the board as a board of arbitration; but the chief purpose of the act is to provide means of investigation, discussion, conciliation and publicity. The board appointed under the law investigates and mediates and advises, but ordinarily does not decide. As its recommendation differs, therefore, from a court's judgment and from an arbitrator's award, the parties and the board are less likely to insist upon unchangeable rules governing future relations: Settlements are not even orders; they are rather agreements, made in the interests of the three parties chiefly concerned: the employer, the employee and the public.

Rather severe penalties are imposed for the suspension of work during investigation: a workman may be fined from $\$$ ro to $\$ 50$ per day for striking (befuse the investigation); an employer may be fined from $\$ 100$ to $\$ 1,000$ per day if he locks out; and a third person, inciting either party to break the law, may be fined from $\$ 5^{\circ}$ - to $\$ 1,000$ for each offense; but the question of enforcing penalties seems seldom to have arisen. The Act provides as to this matter that aggrieved parties may enforce these penalties; it would seem wiser to have this done by some public official. But it is hardly practicable to enforce, in any way, the penalty against a large number of men, if they strike; should each striker demand a separate trial, several years might be consumed in collecting penalties in one strike alone. Practically much more has depended upon the mutual understanding arrived at, and the good will of the parties, than either penalties or public opinion.

It should be observed that experience under our federal act as well as under the Canadian Act, teaches that the chances for conciliation and for satisfactory agreements are better when employees are strongly organized than when they are not. Our former Commissioner of Labor says, speaking of the ERDMAN Acr

"It is difficult to see how its provisions could be carried out with any degree of satisfaction except in cases where organized employees are dealt with. Mucir of the success which has marked the operation of this law is probably due to the fact that the classes of employees with whom it deals are strongly organized and well-disciplined groups."'

And one who has acted many times as chairman of boards under the Canadian Act says of that law:

Bulletin of the Bureau of Labor, No. 98, p. 5 . 
"The law is pretty much a dead letter for any but organized labor."

and a labor member of the Canadian Parliament says:

"The law amounts to practical recognition of trade organizations."

Public opinion having failed in some instances to compel obedience to an award, or to bring about a settlement when no award has been made, compulsory arbitration is urged by many.

Complete compulsory arbitration of industrial disputes by law involves the existence of two essential, prominent features: first, there must be the compulsion of employer and employee to subnit the questions in dispute to arbitration; second, there must be the compulsion of these parties to conform to the decision of the arbitrators.

To make any such law even approximately effective, there must be provided much machinery in detail, but without these two general features, real compulsory arbitration seems impossible.

When we reflect on what this means, we must, it would seem, conclude that it is at least doubtful whether there has been, is now, or ever can be any such thing.

If under some conceivable form of government it could be established and maintained, it is almost certain that its effectual maintenance would be unwise because wasteful.

This view, however; does not make an examination of the subject necessarily unprofitable, for while perfect compulsory arbitration may, perhaps, be impossible, nevertheless something nearly like it may be found to be practicable and desirable, should other means fail to secure a fair degree of industrial peace. Since I89r, when the agitation began in Australia for governmental interference of a drastic nature in industrial disputes, and especially since 1894, when the so-called Compulsory Arbitration LAw was adopted by Australia's neighbor, New Zealand, there has been a great amount of discussion on the subject.

There is much conflict of opinion concerning practical results of the several Australasian experiments. Many find it difficult to understand why it is, if the New Zealand law has accomplished what some say it has, that Viotoria and some other states with similar conditions have adopted different laws; and why it is, if New Zealand is "a country without strikes," as we have been told it is, that recently a wide-spread and bitter strike has been in progress there.

The New Zealand law has been repeatedly amended, and rathét 
recent amendments have served to emphasize its conciliatory and voluntary features. This is important, for after fourteen years of trial it was stated by the advocates of the amendments in the debate on them, that the main principle of the amendments "is to let us go back to conciliation as far as possible."

The law provides for two kinds of boards or tribunals:

First, Councils of Conciliation, and

Second, A Court of Arbitration.

The Councils are four in number, the colony being divided into four districts. Each Council has a chairman appointed for three years, called a commissioner, and when he cannot effect a settlement, assessors (one, two or three in number) are nominated to act with him for the special ucrasion, half of the number being named by each party: thus forming a board of three, five or seven. The efforts of these Councils are directed towards bringing about an agreement: they can make no binding award, but simply recommend terms of settlement. If an agreement is made it is filed and has the effect of an award, or if the recommendations of the Council are not disagreed with by one of the parties within a certain time, they become operative as an award. If a settlement is not thus effected, the dispute is referred to the Arbitration Court of the whole colony.

This Court consists of three members: one is a Judge of the Supreme Court and the others are appointed upon the nomination of employers' unions and employees' unions respectively. The court combines judicial with almost legislative functions, the decision is made by the judge, and the result is that one official may fix wages and other conditions of employment for the whole country.

The law provides for the registration of Industrial Unions of employers or employees. Employees, if fifteen or more in number, wishing to refer a dispute to either the Councils or the Court, must form a union and register under the act, or trade unions already organized may so register; but they must comply with rather strict and minute regulations as to meetings, officers, manner of making industrial agreements, audit of accounts, registration of members, etc., etc. When the Registrar is satisfied on these points, the society is registered and becomes a body corporate, but, as the law reads, "solely for the purposes of this act." "That is, the union surrenders much of its freedom as a voluntary organization in return for the advantage it derives under the law of referring disputes to the tribunals established by the law. Registration renders both the union and its members subject to the jurisdiction of these tribunals. However, if at any time there is no award or agreement binding a particular union, it may cancel its registration and become again a 
voluntary organization, unincorporated, and free to strike and manage its affairs without being subject to the jurisdiction of the Councils or the Court. This explains why strikes are not entirely prevented by this law. "Unlawful strike" or "unlawful lockout" mean, under the law, a strike or a lockout by parties bound by an award or industrial agreement; and a union is not so bound if it has never registered, or if, having registered, it has cancelled its registration.

Penalties of a pecuniary nature in as great a sum as $£_{500}$ are provided for breaches of the awards; and other penalties for unlawful strikes, including formerly imprisonment (if fines were not paid), but imprisonment has been abolished.

The practical operation of the law may be partially illustrated by reference to some decisions and awards made under it as reported in the pamphlets issued by the New Zealand Department of Labor. An offender against an award is prosecuted for the pecuniary penalty in the Magistrate's Court, and the plaintiff prosecuting is a Government Inspector.

Some of the prosecutions reported are as follows: an employer is prosecuted for violating an award made concerning the "Rotorua Tourist Accommodation and Boarding-house Workers" for "employing a porter on his weekly half-holiday," and is fined five pounds and a part of the costs; on the same day the porter employed is also prosecuted for "working on his weekly half-holiday," and the penalty fixed at one pound and part of the costs. .An employer is prosecuted for violating an award concerning shop tailoresses by "failing to pay minimum wage to a journeywoman (three cases)," and is fined, while on the same day the three employees involved are prosecuted and fined for "failing to claim minimum wage." An Auckland butcher is prosecuted and fined for the offense of "employing more than the proportion of youths to men allowed by award."

Awards under the law are often for three years, and establish conditions of employment for the period named.

The awards generally contain what is called the "preference clause" of which the following is an example:

\section{"Preference.}

4. (a.) It shall be the duty of every employer when engaging a worker to ascertain whether he is a member of the workers' union, and if he is not a member of such union the employer shall notify the secretary of such union accordingly within seven days from the time of engaging such worker. 
(b.) It shall be the duty of every non-unionist engaged as aforesaid to join the workers' union within seven days after receiving from the secretary of the union a request in writing to do so, and to remain a member thereof.

(c.) The foregoing provisions of this clause shall operate only if and so long as the rules of the union shall permit any person of good character to become and remain a member of the union, without ballot or other election, on payment of an entrance fee not exceeding $5 \mathrm{~s}$., and of subsequent contributions, whether payable weekly or otherwise, not exceeding $6 \mathrm{~d}$. per week."

The encouragement to unions given by the New Zealand law is so direct as to amount aimost to compulsory unionism, while the encouragement which the ERDMAN-NEWLANDS ACT and the CANADIAN INDUSTRIAL DISPUTES INVESTIGATION ACT give to labor organizations is indirect, yet effective: in fact, all laws for official conciliation and arbitration seem practically to bring about "recognition of the union" in one form or another. This New Zealand law, besides thus emphasizing the labor union and collective bargaining, establishes the minimum wage. It thus creates a system of governmental regulation of wages and conditions of labor applying to about every industry in the entire country.

It is not likely that we shall see exactly such a law in this country: the lack of uniformity in state laws of this character, or in their administration, that would almost certainly exist, would be a grave objection, were there no others. While this law interferes with freedom of contract, it should be noticed that it does not attempt to compel an employer to carry on his business, nor to compel a workman to work under what he regards as objectionable conditions: the law in effect simply directs that after an award of the court has been made, the business, - if conducted, must be conducted in a certain manner, and the workman, if he works, must work under prescribed conditions. This aspect of the law is not entirely bad. Something like this has been prescribed by Courts in this country without any statute. For example, during the trouble arising from the Pullman strike in 1894 some railroad employees refused to haul Pullman cars, but they were ordered by the Court to perform this duty while they continued to work for the railroad company. ${ }^{5}$

The law does not attempt to accomplish the impossible thing of actually compelling a large number of men to work against their

s Southern California Ry. Co. v. Rutherford, 62 Fed. 796; and see Toledo, Ann Arbor etc. Ry. Co. v. Pennisylvania Co. et ad., 54 Fed. $746,756$. 
wills. The constitutional objection to it on the ground that it violates the provision of the Thirteenth Amendment against "involuntary servitude," seems therefore hardly tenable.

Irrespective of this constitutional provision, no court would attempt to coerce men to work, or employers to operate their business. ${ }^{0}$ The only instance in this country where men in civil life may be forced to work in accordance with the terms of their contractactually seized and held and compelled to work-is to be found in the law relating to sailors. The Supreme Court of the United States has held that statutes enabling seamen's contracts to be carried out in this manner do not violate the Thirteenth Amendment, because their contracts are exceptional, and the necessities of the public justify the enforcement of a sailor's contract by exceptional means.? Obviously, it is more practicable to make sailors work after you have seized them and taken them aboard ship than it is to make men work on land. As Dr. JoHnson said, sea-life is "perpetual imprisonment with the chance of drowning." But the interesting matter to note in this connection is that an exception once having been made, and madepartly on account of "the necessities of the public,"8 another exception may be made, quite as constitutionally, should it be necessary for the public welfare in the case of "public utilities" and industries of like character.

But it may be said that under the principles of the "peonage" cases as announced by the Supreme Court of the United States and some of the State Courts, a statute may not, without violating the "involuntary servitude" clause of the Thirteenth Amendment, attempt to do indirectly what it cannot do directly. That is, it cannot be made by statute a crime to violate service contracts and then this crime be made punishable by fine or imprisonment; and it might be argued that this is substantially what a law like New Zealand's law provides.

It has been suggested, however, that this is not quite a correct view. For when a union registers under the act, it surrenders for itself and its members certain rights in return for certain advantages accruing from arbitration; and it surrenders these rights partly for the general public good; when, then, it is punished for striking against an award, it is punished, not for failing to work in accord-

- Arthur v. Oakes, 63 Fed. 3ro; Roquemore et al. v. Mitchell Bros., 167 Ala. 475; Web5 v. England, 29. Beav. 44.

2 Robertson v. Baldwin, 165 U. S. 275.

8 Patterson v. Bark Eudora, 190 U. E. 16g. 275.

- Bailey v. Alabama, 219 U. S. 219, 244 ; State v. Amstead, 103 Miss. -, 60 So. 778. 
ance with the award, nor for striking, but rather for breaking a contract with the public.

This theory of the matter is suggestive of arguments which tend to refute objections to such a law made also under the Fifth and Fourteenth Amendments to the Constitution of the United States.

These arguments do not apply to a law intended to regulate every kind of industry as strongly as they apply to industries affected with a public interest: that is, to public utilities and to industries having to do with the production and distribution of necessary commodities.

When we examine the decisions of the United.States Supreme Court for the last twenty-five years-more especially, too, for the last fifteen years-we see a multitude of instances where the reserved police power of the States has been held to have been lawfully exercised though it has interfered in all sorts of ways with the security of person and property and the freedom of contract assured by the Fourteenth Amendment.

Some of the general expressions of the court in deciding these cases are worth noting.

The bank guarantee laws of Oklahoma, Kansas, and Nebraska were sustained under the State's police power which the court says "extends to all great public needs;" Justice Hormes saying further:

"It [police power] may be put forth in aid of what is sanctioned by usage, or held by the prevailing morality or strong and preponderant opinion to be greatly and immediately necessary to the public welfare."10

In a recent decision sustaining an ordinance regulating the weight of bread loaves, the court says:

*** "there is no absolute freedom of contract; limitations are constantly imposed upon the right of contract freely, because of restrictions upon that right deemed necessary in the interest of the general zelfare."11

In an earlier case, the court says:

"The possession and enjoyment of all rights are subject to such reasonable conditions as may be deemed by the governing authority of the country essential to the safety, health, peace, good order and morals of the community;"12 and again it says:

10 In Noble State Bank v. Haskell, 219 U. S. 104, 111 ; Shallenberger v. First State Banh, 219 U. S. 114; Assaria Bank v. Dolley, 219 U. S. 121.

4 Schnidinger v. Chicago, 226 U. S. 578.

12 Crowley v. Christiansen, I37 U. S. 86, 89. 
"The State may interfere wherever the public interests demand it, and in this particular a large discretion is necessarily vested in the legislature to determine not only what the interests of the public require, but what measures are necessary for the protection of such interests." ${ }^{13}$

What Marshali said of the Constitution as it was in his day is true of such general provisions as have since been added to it. He said that it

"was intended to endure for ages to come, and to be adapted to the various crises in human affairs." 14

It is a mistake to suppose that the Constitution stands in the way of progress: its very generality makes possible its adaptation to changing conditions.

Our highest court has sustained on these general principles legislation of the states in the following cases, to select a few from very many: under various sanitary and food laws our bread and milk, bread and butter and jam are regulated; we may not buy cigarettes or liquor; we must work only a certain number of hours and receive our wages in a certain way, and at a certain time (these latter laws, by the way, are not sustained simply because they promote the welfare of those supposed to be at an economic disadvantage, but as well because they promote the general welfare); we must erect buildings not to exceed a certain height; we must be vaccinated; we may insist on our school children being carried for half-fare on street railways; railroad rates may be regulated and also the rates of grain elevators, telephone, gas, and water supply companies. Several hundred laws of similar character have been held by the court to be valid and riot to have denied the complaining parties the equal protection of the laws, nor to have deprived them of liberty or property without due process of law.

All this being so, does the Constitution of the United States prevent the exercise in a reasonable, unarbitrary manner of a state's. police power to establish something closely approaching compulsory arbitration, applicable to public service corporations and their employees, and to those engaged in supplying the public with necessary commodities? It seems it does not.

It is an old principle of law that virtual monopolies may be regulated in the interest of the public, and, under our decisions, to what extent this regulation shall go is largely discretionary with the

13 Lawton v. Steele, I52 U. S. I33, 136 .

14 McCulloch v. Maryland, 4 Wheat. 316, 415. 
legislative authority, and is dependent largely on the exigencies of the case.

Government exists for the public good; certain kinds of services are performed, and virtual monopolies are acquired under Government also for the public good; their nature makes them public agencies; when the people find that those conducting these agencies conduct them as if they were entirely their own affairs, for private advantage, and also permit the operation of the agency to be interrupted by quarrels among themselves-then, if fundamental principles are of value, the people should be able to intervene through government to protect their inter ests and to see that justice is done.

The principles of compulsory arbitration are not wholly unfamiliar to us. People who think "there is nothing to arbitrate" respecting the title to their land, etc., are compelled every day to come to court. But a closer analogy to arbitration of labor disputes is to be found in the public regulation of railroad rates. This compulsory arbitration between shippers and railroads, between the consumer and the producer, was objected to by the railways as both impracticable and unconstitutional, but it is an accomplished fact.

There appears to have been no decision in this country upon the precise legal questions involved in the matter of "compulsory arbitration." The nearest approach to a decision on the subject seems to be the answer by the Supreme Court of Colorado in 1886 to questions as to a certain proposed law: the terms of the law are not set out, there is no discussion, the whole matter is reported in thirteen printed lines, and the decision was that a particular section of the State Constitution relating apparently to private arbitration by mutual agreement did not contemplate, nor admit of, a law providing for compulsory submission of differences to arbitration: other constitutional provisions were not considered. ${ }^{15}$ If necessary, constitutions may be amended: those of many of out states are easily amendable.

If constitutional, how far is compulsory arbitration practicable? Irrespective of pecuniary penalties, which are often uncollectable, strikes may, it is true, sometimes be broken by arresting the strike leaders.

Mr. Derss testified before the Pullman Strike Commission appointed by President CLEVEIAND in 1894 that the Courts broke the strike by removing the leaders from the scene of action. ${ }^{16}$

\footnotetext{
15 In the matter of " $A$ Bill for an Act to provide for the amicable adjustment of grievances and disputes that may arise between employers and employees, etc," 9 Colo. 629.

18 See United States v. Debs, 64 Fed. 724, 759.
} 
Moreover, while it is true that a court will not compel men to work in a certain place, it might, perhaps, without violating settled principles, prevent their working elsewhere.

Decisions against employers may be "enforced" by fines, or by the appointment of a receiver to conduct the business in accordance with the award.

While, therefore, ways may be suggested by which some of the objections to compulsory arbitration may be met, nevertheless it seems certain that there are better ways than this of bringing about industrial peace.

Our aim should be not to try to prevent strikes at all hazards, but to provide proper conditions of labor, and when differences arise which cannot be composed by the parties, to supply some prompt, competent, and just tribunal whose decision will carry such weight because of its promptness, competency, and justness, as to enforce itself without penalties. We should aim to establish permanent peace and good will, and not merely an intermission of hostilities.

The following conclusions seem reasonable.

In the first place an educative process is desirable by which all can be made to see, what experience seems clearly to teach, that "collective bargaining" is the best preventive of such social disorders, as well as the best cure for them when they have occurred.

Let the labor union speak as employers speak through chosen representatives; strengthen its self-respect by dealing with it; increase its legal liability, if you will, by enactments enabling it to sue and be sued; but also avoid constant suspicion, and put it on its honor; regard it as what it is-one necessary means of social amendment-and a long step has been taken towards permanent peace. As suggested above, a properly administered law like that of Wisconsin (IgII) will prevent disputes, but in order that it may operate effectively and make unnecessary other legislation, it would seem that organization of both employers and employees should be fostered.

In the second place, urge the principle of voluntary arbitration where collective bargaining has brought no results. No legislation is necessary for this.

Third, provide by legislation some means by which, when the parties refuse both to bargain and to arbitrate, there may be compulsory official investigation. This may be at the request of one of the parties, or at the instance of some public official when the public interest demands it. The best parts of the ERDMAN-NEwLANDS ACT and the CANADIAN INDUSTRIAL Disputes INvestiga- 
TION ACT furnish models for such a law. This simply affords machinery for getting at the truth. As an incident, strikes and lockouts may be prohibited during the investigation, but the only other compulsion in this law should be that which is quite reasonable in the circumstances, namely compulsory investigation. After that, moral suasion should be relied on, rather than coercion. If convicts can be put on their honor and trusted to build roads without guards, it ought not to be necessary to coerce workingmen or employers.

And then as a last resort, when other more reasonable methods fail, we may provide for "compulsory arbitration" within the limits above suggested.

University of Colorado.

James H. Brewster. 